\title{
Inhibitors of arachidonic acid metabolism reduce DNA and nuclear fragmentation induced by TNF plus cycloheximide in U937 cells
}

\author{
Daina M Vanags ${ }^{1}$, Pontus Larsson², Stina Feltenmark ${ }^{2}$, \\ Per-Johan Jakobsson ${ }^{2}$, Sten Orrenius ${ }^{1}$, Hans-Erik Claesson ${ }^{2}$ \\ and Miguel Aguilar-Santelises ${ }^{1}$ \\ 1 Division of Toxicology, Institute of Environmental Medicine, Karolinska \\ Institute, Stockholm, Sweden \\ 2 Department of Medical Biochemistry and Biophysics, Karolinska Institute, \\ Stockholm, Sweden \\ ${ }^{3}$ corresponding author: M Aguilar-Santelises, M.D. Institute of Environmental \\ Medicine, Division of Toxicology, Karolinska Institute, Box 210, S-171 77, \\ Stockholm, Sweden. fax: -46-8-32-59-86
}

Received 29.11.96; revised 6.3.97; accepted 10.4.97

Edited by P. Cohen

\begin{abstract}
U937 human myeloid leukemia cells are induced to apoptosis by tumour necrosis factor (TNF) plus cycloheximide (CHX). We have analysed the effect of various inhibitors of the arachidonic acid (AA) metabolism on several features of this process. The formation of high molecular weight and oligonucleosomal DNA fragments as well as nuclear fragmentation were reduced by inhibitors of 5-lipoxygenase (BWA4C and BWB70C), 5-LO activating protein (MK-886), and cytosolic PLA (AACOCF $_{3}$ ). None of these agents blocked the morphological changes detected by microscopy or flow cytometry, phosphatidylserine exposure on the cell surface or Caspase 3-like activation. AA also induced nuclear fragmentation at a concentration of 1-20 $\mu \mathrm{M}$. However, the mechanisms by which these inhibitors act, remain unexplained since there was no 5-LO expression in the U937 cells and no AA release followed their stimulation with TNF plus $\mathrm{CHX}$.
\end{abstract}

Keywords: arachidonic acid, cytosolic phospholipase $A_{2}$, 5-lipoxygenase, TNF, U937, apoptosis

\footnotetext{
Abbreviations: MW, molecular weight; $\mathrm{CHX}$, cycloheximide; TNF, tumour necrosis factor, 5-LO, 5-lipoxygenase; FLAP, 5lipoxygenase activating protein; $\mathrm{CPLA}_{2}$, cytosolic $\mathrm{PLA}_{2}$; $\mathrm{PS}$, phosphatidylserine; AA, Arachidonic acid; ICE, interleukin-1 $\beta$ converting enzyme; 5-HPETE, 5-hydroperoxy-eicosatetraenoic acid; 5-HETE, 5-hydro-eicosatetraenoic acid $\mathrm{LTA}_{4}$, leukotriene $\mathrm{A}_{4}$; $\mathrm{LTB}_{4}$, leukotriene $\mathrm{B}_{4} ; \mathrm{PGH}-1$, prostaglandin-1 synthase or cyclo-oxygenase-1; $\mathrm{PGH}-2$, prostaglandin-2 synthase or cyclo-oxygenase-2; DEVD-AMC, Ac-Asp-GluVal-Asp-amino-4-methylcoumarin; DEVD-CHO or aldehyde, Ac-Asp-Glu-Val-Asp-CHO
}

\section{Introduction}

Tumour necrosis factor (TNF, also known as cachectin or $\mathrm{TNF}_{\alpha}$ ) is a polypeptide mediator of inflammation and cellular immune responses (Aggarwal and Natarajan, 1996). Upon binding to its cell surface receptor, TNF initiates apoptosis and the transcription of protective genes by processes that are not yet well understood (Beyaert and Fiers, 1994). Apoptosis is an intrinsic suicide mechanism that occurs as consequence of physiological or pathological processes (Fraser and Evan, 1996). It can be induced by diverse stimuli which cause characteristic morphological and biochemical changes leading to cell death (Steller, 1995).

TNF induces the activation of interleukin- $1 \beta$-converting enzyme (ICE)-like proteases such as CPP32 (caspase 3) which appear to be essential for the cell death mechanism (Tewari et al, 1995; Zhivotovsky et al, 1996). TNF also induces a number of cell signals that include activation of cytosolic Ser/Thr protein kinases (Beyaert and Fiers, 1994), and phospholipase $A_{2}\left(P_{2} A_{2}\right)$ (Neale et al, 1988; Hollenback et al, 1992; McEwan, 1996), ceramide production and superoxide radical generation (Aggarwal and Natarajan, 1996). The ability of TNF to induce AA release and activate the enzymes involved in its metabolism, has prompted the suggestion that this pathway may be an important regulator of cell survival (Schutze et al, 1992; Tang et al, 1996; Voelkel-Johnson et al, 1996).

Arachidonic acid (AA) metabolism begins with $\mathrm{CPLA}_{2}$ catalysing the release of $A A$ from cell membrane phospholipids (Dennis, 1994). 5-Lipoxygenase (5-LO) catalyses the conversion of AA to 5-hydroperoxy-eicosatetraenoic acid (5-HPETE) which can be degraded either to 5-hydroxyeicosatetraenoic acid (5-HETE) or leukotriene $A_{4}$ $\left(\mathrm{LTA}_{4}\right)$, that can then be metabolised to $\mathrm{LTB}_{4}$. Other important contributors to AA metabolism include 5-LO activating protein (FLAP), which is required for optimal cellular leukotriene synthesis (Claesson et al, 1992) and prostaglandin (PGH) synthases (also known as cyclooxygenases) which catalyse the conversion of $A A$ to prostaglandins and thromboxanes (Hamberg et al, 1975). The effect of various $\mathrm{PLA}_{2}$, lipoxygenase (LO) and prostaglandin synthase ( $\mathrm{PGH}$-synthase) inhibitors is unclear, since they have been associated both with induction of (Anderson et al, 1993, 1995; Tsujii and Dubois, 1995; Tang et al, 1996) and protection from apoptosis (Chang et al, 1992; Agarwal et al, 1993; O'Donnell et al, 1995).

To investigate the link between AA metabolism and apoptosis, we have studied the events that occur when U937 cells are exposed to TNF plus cycloheximide (CHX). Previous studies have used non-specific inhibitors such as NDGA, which is an antioxidant that can inhibit both LO and 
PGH synthases (Chang et al, 1992; O'Donnell et al, 1995). Instead, we have studied the effect of the until now considered specific 5-LO inhibitors BW A4C and BW $\mathrm{B} 70 \mathrm{C}$. We have also used MK-886, a FLAP inhibitor that interferes with substrate binding to 5-LO (Gillard et al, 1989; Ford-Hutchinson et al, 1994), and $\mathrm{AACOCF}_{3}$, a specific inhibitor of $\mathrm{CPLA}_{2}$ (Riendeau et al, 1994). Here, we report that these compounds inhibit nuclear but not cytoplasmic features of apoptosis induced by TNF plus CHX in U937 cells.

\section{Results}

\section{Induction of apoptosis}

TNF plus CHX induced features of apoptosis in U937 cells, occurring simultaneously with trypan blue exclusion over a $5 \mathrm{~h}$ time course. U937 cells were analyzed by FACS (Figure 1). Changes in forward scatter (FSC) and side scatter (SSC) were apparent after $2 \mathrm{~h}$ incubation with TNF plus $\mathrm{CHX}$. The number of cells in gate 1 (to the right) decreased, with correspondent increasing values in gate 2 (to the left), which included cell fragments and cells with diminished size (Figure 1A). From 10000 cells that were originally in gate 1 , there was a decrease to $5956 \pm 1575$ cells at $5 \mathrm{~h}$, which was significantly different $(n=4 ; P<0.05)$ when compared to cells incubated with ethanol alone. However, the effect of incubating U937 cells with TNF plus $\mathrm{CHX}$ and the inhibitors was not different from the effect induced by TNF plus $\mathrm{CHX}$ alone (Figure 1B).

\section{PS exposure}

PS exposure was detected using FITC-Annexin binding assay, after $2 \mathrm{~h}$ treatment of U937 with TNF plus CHX. Again, no inhibitory effect on annexin binding was obtained when TNF plus CHX-stimulated cells were incubated in the presence of the inhibitors as illustrated with AACOCF3 in Figure 2.

\section{Caspase 3-like activity}

TNF plus $\mathrm{CHX}$ stimulated an increase in Caspase 3-like enzyme activity in U937 cells after 90 min (Table 1), which is inhibitable by DEVD-CHO, a specific inhibitor of Caspase 3like enzymes (Vanags et al, 1996). Inhibitors of AA metabolism were incubated with U937 cells in culture stimulated with TNF and $\mathrm{CHX}$, but none of the inhibitors had a significant effect on Caspase 3-like enzyme activity (Table 1).

\section{5-LO, FLAP and $\mathrm{CPLA}_{2}$ inhibitors reduce nuclear and DNA fragmentation}

TNF plus $\mathrm{CHX}$ induced nuclear fragmentation which was increased over the $5 \mathrm{~h}$ time course (Figure 3). However, the

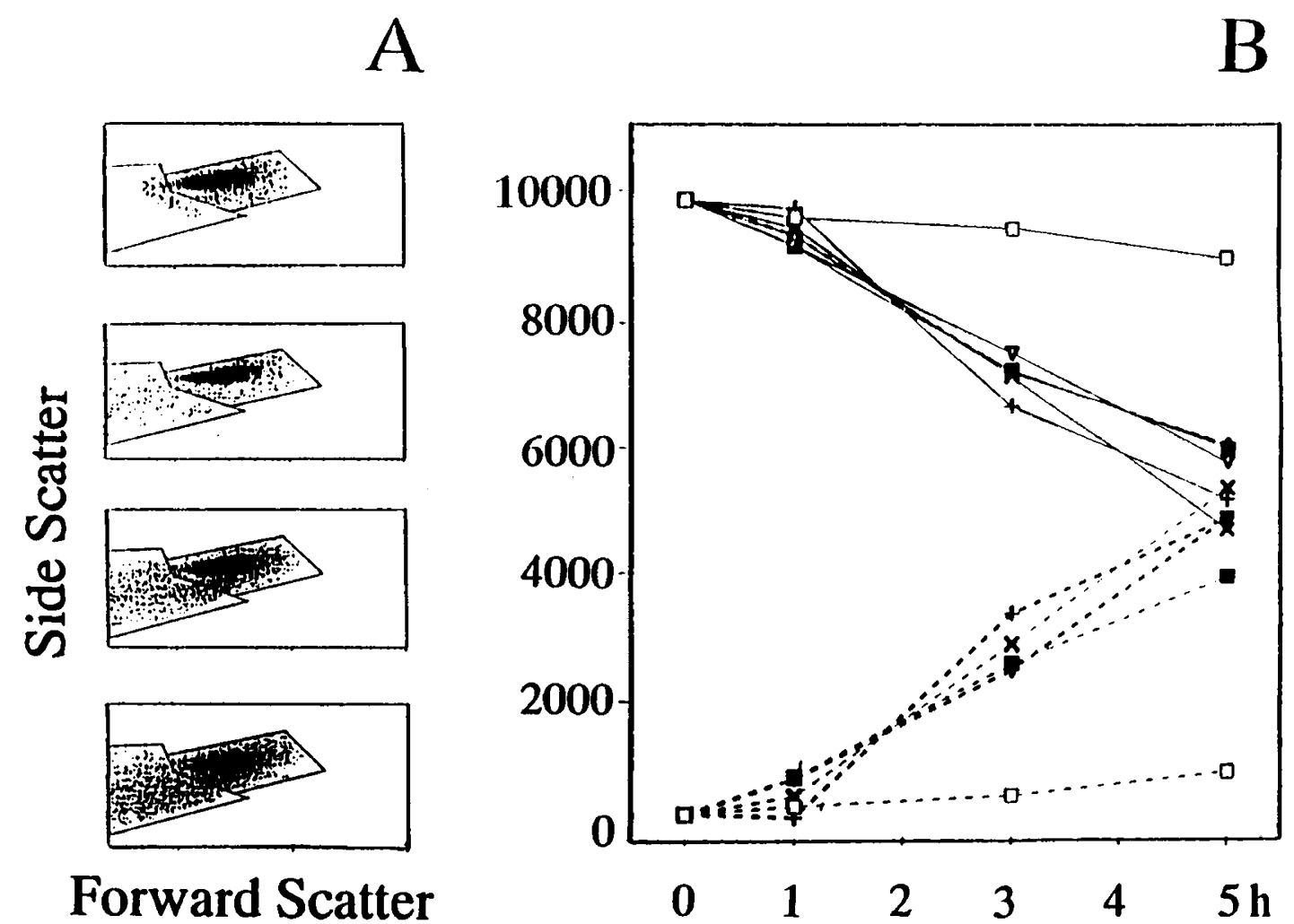

Figure 1 Cellular fragmentation and shrinkage. U937 cells were collected at different time points during incubation with TNF (12 ng/ml) plus CHX ( $1 \mu \mathrm{g} / \mathrm{ml})$, and analyzed by flow cytometry. (1A) shows dot plots corresponding to $0,1,3$ and $5 \mathrm{~h}$ (from top to bottom). 10000 cells were analyzed by linear FSC vs logarithmic SSC. Gate 1 (to the right) includes cells with the initial morphology, while Gate 2 (to the left) includes cells with altered size and density. (1B) shows cell numbers in Gate 1 (continuous lines) and Gate 2 (discontinuous lines) during the $5 \mathrm{~h}$ incubation with ethanol ( $\square$ ) or TNF plus CHX, alone ( $\square$ ) or in the presence of BW A4C (X), BW B70C $(\triangle)$, MK-886 (+), and $\operatorname{AACOCF}_{3}(\nabla)$. 
number of cells with nuclear fragmentation was decreased when they were incubated in the presence of 5-LO, FLAP and $\mathrm{CPLA}_{2}$ inhibitors. This inhibition was dose dependent, with maximal effect at $10 \mu \mathrm{M}$ concentration of each one of the inhibitors $(P<0.05$, Figure 4$)$.

Treatment with TNF plus $\mathrm{CHX}$ also induced the formation of high MW and oligonucleosomal DNA fragments. DNA fragmentation was inhibited when the cells were incubated in the presence of BWA4C, BWB7OC, and

A
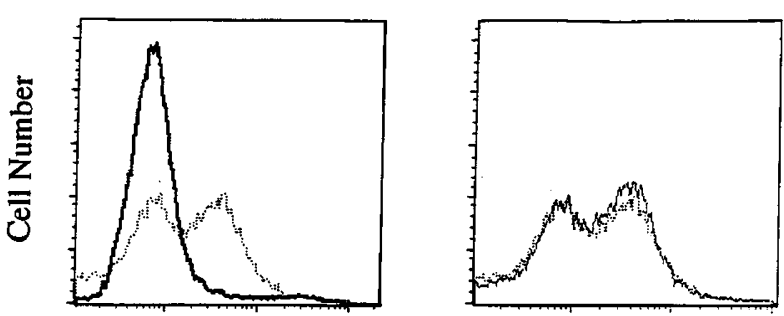

Mean Fluorescence Intensity

Figure 2 PS exposure on the surface of U937 cells. (A) Annexin V-FITC binding from U937 cells not treated (continuous line) or treated with TNF plus CHX (dotted line). (B) Annexin V-FITC binding of TNF plus CHX treated cells in the presence (continuous line) or in the absence (dotted line) of AACOCF $_{3}$.

Table 1 DEVD-AMC cleavage in U937 cells

\begin{tabular}{lc}
\hline & AMC released (pmoles/min) \\
\hline Medium & $2.0 \pm 0.5$ \\
Ethanol & $3.0 \pm 1.0$ \\
TNF plus CHX & $24.0 \pm 12.0$ \\
TNF plus CHX and BW A4C & $26.0 \pm 11.0$ \\
TNF plus CHX and BW B70C & $21.0 \pm 11.0$ \\
TNF plus CHX and MK-886 & $24.0 \pm 13.0$ \\
TNF plus CHX and AACOCF & $20.0 \pm 9.0$ \\
\hline
\end{tabular}

DEVD-AMC cleavage was assessed in a kinetic assay monitoring pmol of AMC released over time. $V_{0}$ maximum (pmoles $/ \mathrm{min}$ ) was estimated from linear regressions $\left(r^{2}>0.99\right)$ after U937 cells were incubated with the inhibitors $(10 \mu \mathrm{M})$. Data are mean \pm s.e. of three experiments done in triplicate.

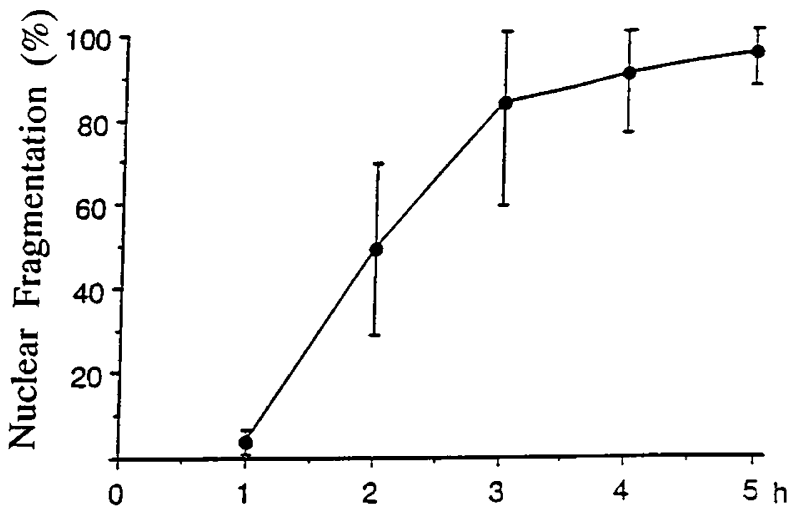

Figure 3 Percentage of nuclear fragmentation induced in U937 cells during $5 \mathrm{~h}$ time course incubation with TNF $(12 \mathrm{ng} / \mathrm{ml})$ plus $\mathrm{CHX}(1 \mu \mathrm{g} / \mathrm{ml})$.
MK-886 in a range of concentrations between 0.1 and $10 \mu \mathrm{M}$ (Figure 5A and $\mathrm{B}$ ). High MW DNA fragments were decreased in the presence of $1 \mu \mathrm{M} \mathrm{AACOCF}$, but not in the presence of ethanol alone. Incubating the cells with TNF, CHX or the inhibitors alone did not result in DNA fragmentation (not shown).

\section{Enzyme expression by RT-PCR}

The expression of the key enzymes for AA degradation was analysed at transcriptional level. Our U937 cell clone was positive for $\beta$ actin, cPLA, FLAP, $\mathrm{LTA}_{4}$ and PGH-1
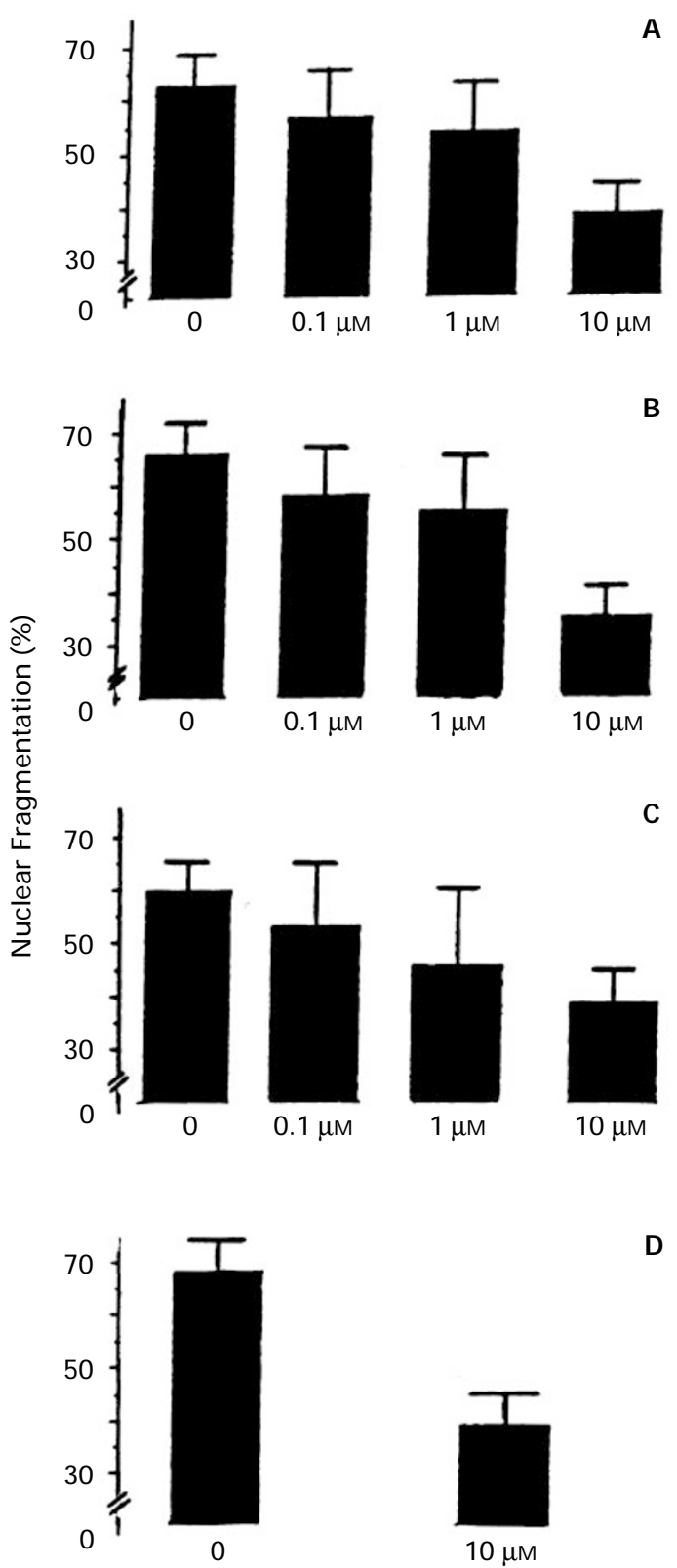

Figure 4 Percentage of nuclear fragmentation in U937 cells induced by TNF $(12 \mathrm{ng} / \mathrm{ml})$ plus $\mathrm{CHX}(1 \mu \mathrm{g} / \mathrm{ml})$ after $3 \mathrm{~h}$ in the presence of BW A4C $(\mathbf{A})$, BW $\mathrm{B} 70 \mathrm{C}$ (B), MK-886 (C), or $\mathrm{AACOCF}_{3}$ (D). Inhibition reached statistical significance $(n=4, P<0.05)$ with every compound at $10 \mu \mathrm{M}$ concentration. 
A
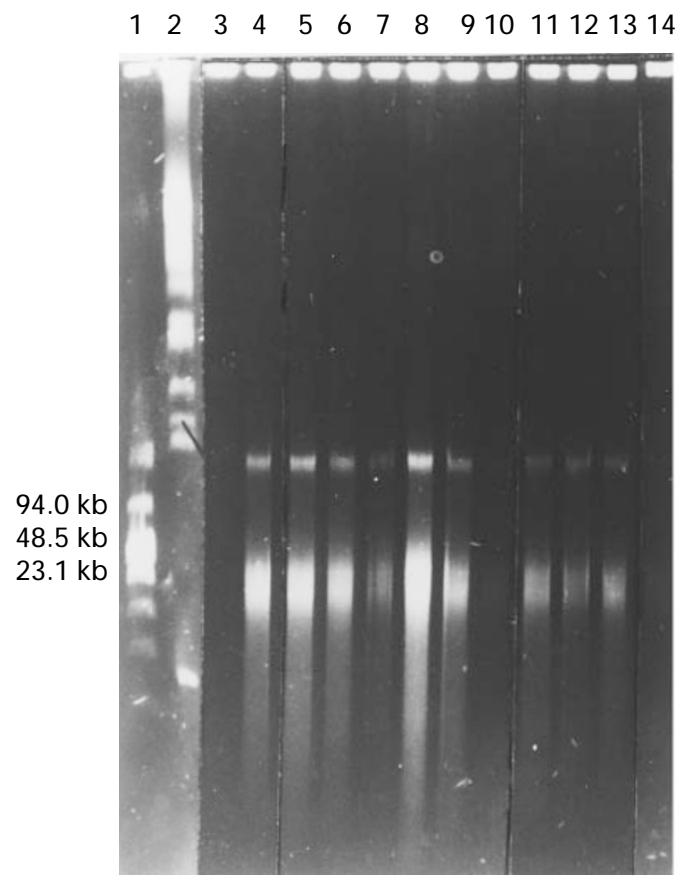

B $\begin{array}{llllllllllll}3 & 4 & 5 & 6 & 7 & 8 & 9 & 10 & 11 & 12 & 13\end{array}$

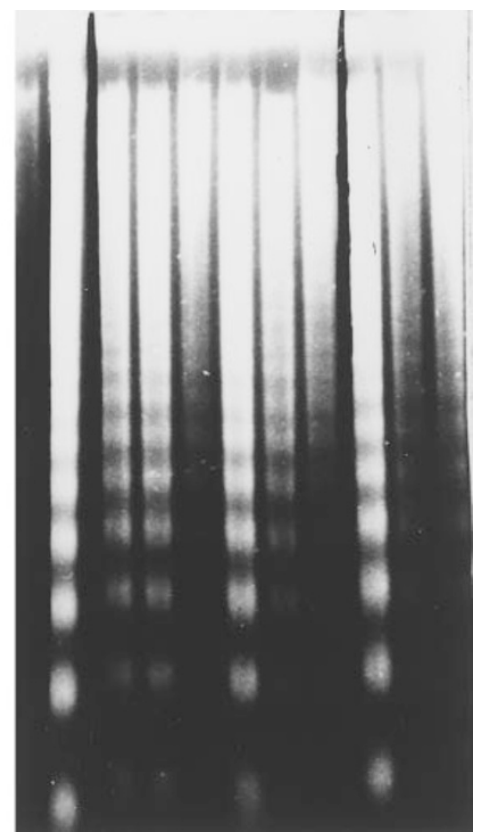

>Figure 5 Analysis of high MW (A) and oligonucleosomal (B) DNA fragments. Lane 1 corresponds to MW marker from 0.1 to $200 \mathrm{~kb}$, lane 2 to MW marker from 225 to $2200 \mathrm{~kb}$, and lane 3 to U937 cells incubated with ethanol $0.1 \%$. U937 cells were incubated with TNF (12 ng/ml) plus CHX (1 $\mu \mathrm{g} / \mathrm{ml})$ alone (lane 4$)$, or in the presence of BW A4C (lanes 5, 6, 7), BW B70C (lanes 8, 9, 10), or MK-886 (lanes 11, 12, 13) at $0.1 \mu \mathrm{M}, 1 \mu \mathrm{M}$ and $10 \mu \mathrm{M}$. U937 were also incubated with TNF plus $\mathrm{CHX}$ and $1 \mu \mathrm{M} \mathrm{AACOCF}$ (lane 14).

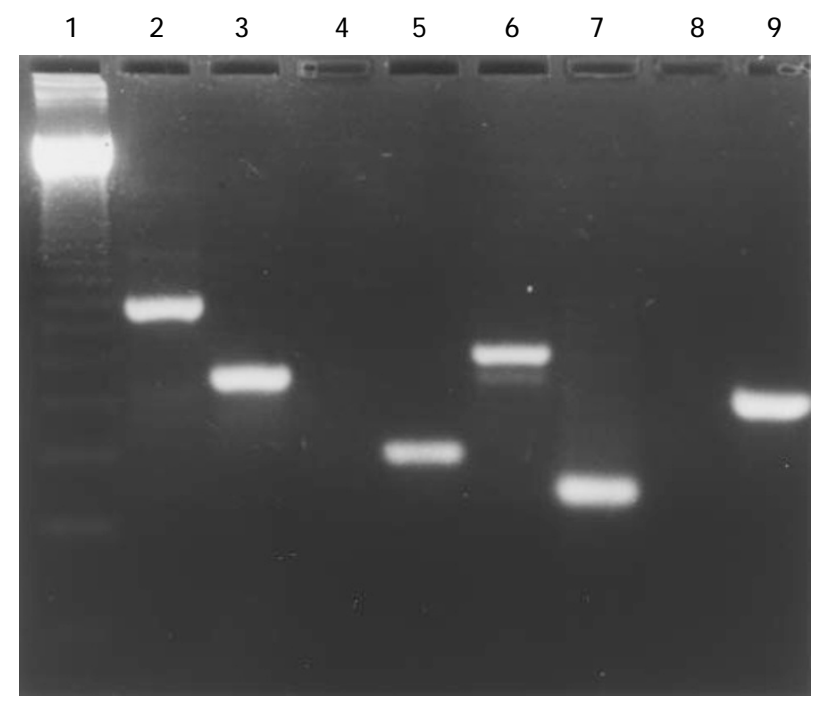

Figure 6 Analysis of cDNA from U937 cells by RT-PCR. Lane 1 corresponds to a $123 \mathrm{bp}$ molecular marker, and the following lanes correspond to $\beta$ actin (2), $\mathrm{CPLA}_{2}$ (3), 5-LO (4), FLAP (5), $\mathrm{LTA}_{4}$ hydrolase (6), PGH-1 synthase (7) and PGH-2 synthase (8). Positive amplification of the BL41-E95-A lymphoma cell line for 5-LO is shown in lane 9 .

synthase, whereas it was negative for 5-LO and PGH-2 synthase (Figure 6). There was no 5-LO protein detected by Western blot and no leukotriene synthesis was found by HPLC (not shown). Positive 5-LO amplification was obtained with cDNA from the BL41-E95-A lymphoma cell line (Figure 6). Positive amplification for $\mathrm{PGH}-2$ was obtained with cDNA from normal human leukocytes and from human umbilical cord vein endothelial cells (not shown).

\section{CPLA $_{2}$ inhibition by BW A4C, BW B70C, MK-886 and $\mathrm{AACOCF}_{3}$}

BW A4C and BW B70C, as well as MK-886, are considered selective inhibitors for 5-LO (Garland and Hodgson, 1994) and FLAP, respectively (Ford-Hutchinson et al, 1994). However, we found that the three compounds partially inhibited $\mathrm{CPLA}_{2}$ activity, purified approximately 500-fold from U937 cells, at the same concentrations that were effective for inhibition of apoptosis (not shown). $\mathrm{AACOCF}_{3}$ was the most potent $\mathrm{CPLA}_{2}$ inhibitor, allowing only $7.9 \pm 0.2 \%$ of the activity from the control, when present at $1 \mu \mathrm{M}$ concentration. $\mathrm{AACOCF}_{3}$ decreased also $\mathrm{CPLA}_{2}$ activity in the presence of TNF plus $\mathrm{CHX}$ in total cellular homogenates (Figure 7). However, we could not find an increase in $\mathrm{CPLA}_{2}$ activity in the homogenate of cells stimulated with TNF plus $\mathrm{CHX}$ after short (0 to $10 \mathrm{~min}$; Figure 7) or long time exposure (0 to $3 \mathrm{~h}$; not shown). We did neither find AA release from intact U937 cells stimulated with TNF plus $\mathrm{CHX}$, both in the presence or in the absence of serum (not shown).

\section{Apoptosis induction by AA}

In order to investigate whether $A A$ itself could induce apoptosis, we incubated $U 937$ cells with $A A$ at various 


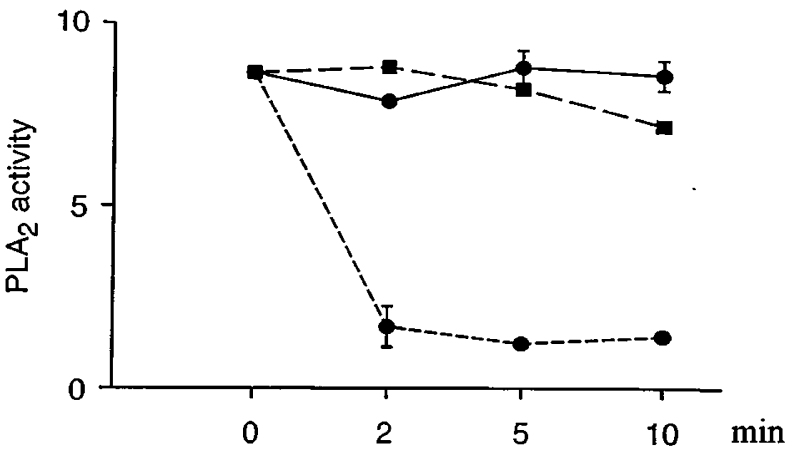

Figure 7 cPLA 2 activity in U937 cell homogenates. Cells were stimulated for the indicated times, and thereafter homogenised. The activity is expressed as released $\mathrm{pmol}{ }^{14} \mathrm{C}-20: 4 / \mathrm{mg}$ protein/min. Graphs correspond to $\mathrm{CPLA} \mathrm{A}_{2}$ activity of untreated (-O-O), TNF plus CHX treated (口- - - - $\mathbf{-}$ ) or TNF plus $\mathrm{CHX}$ treated cells, preincubated with $10 \mu \mathrm{M} \mathrm{AACOCF}_{3}(\mathbf{0}-\mathbf{0}-\mathbf{0})$.

concentrations for increasing periods of time. AA induced a significant nuclear fragmentation, dose and time dependent, although not as much as that induced by TNF plus $\mathrm{CHX}$ (Table 2).

\section{Discussion}

In the present study we have shown that BW A4C, BW B70C, MK-886, and $\mathrm{AACOCF}_{3}$ inhibit nuclear events in U937 cells undergoing apoptosis. Since U937 cells do not produce leukotrienes and lack 5-LO (Claesson et al, 1993), neither 5-LO or FLAP inhibition could explain the inhibition of apoptosis by these compounds. At the concentration range used BW A4C, BW B70C and MK-886, like AACOCF 3 also inhibited $\mathrm{CPLA} \mathrm{A}_{2}$ enzyme activity. Furthermore, we have shown that $\mathrm{AA}$, the product of $\mathrm{CPLA} \mathrm{A}_{2}$ activation is able to induce apoptosis in U937 cells. However, we failed in demonstrating an increase in $\mathrm{CPLA}_{2}$ activity or extracellular AA release after treatment of U937 with TNF plus $\mathrm{CHX}$. Although the effect of these inhibitors may help to make a distinction between nuclear and cytoplasmic events of apoptosis, their mechanisms of action remain an open question.

BW A4C and BW B70C, are analogues of AA containing an hydroxamic acid (BW A4C) or N-hydroxyurea (BW B70C) group linked to a lipophilic aryl unit. They seem to inhibit 5-LO by scavenging lipid peroxides at the active site of the enzyme (Garland and Hodgson, 1994). MK-886, a thiopyranindole structure is also considered a selective inhibitor of the 5-LO pathway and acts by binding to FLAP and inhibiting 5-LO translocation to nuclear membranes. MK886 has been described as not affecting 5-LO or $\mathrm{PLA}_{2}$ (Gillard et al, 1989; Ford-Hutchinson et al, 1994), although we have shown that it does in fact inhibit $\mathrm{cPLA}_{2}$ activity. This discrepancy might be due to different assay systems used for the determination of $\mathrm{CPLA}_{2}$ activity. Mechanistically, it is likely that the lipophilic aryl moiety localises the inhibitors in the phase of the cell membrane at which $\mathrm{CPLA}_{2}$ is active (Garland and Hodgson, 1994) and probably interferes directly with the $\mathrm{CPLA}_{2}$ enzyme, independent of substrate concentration (Tanaka et al, 1992).
Table 2 Nuclear fragmentation induced by AA

\begin{tabular}{lcrcc}
\hline & $\mathbf{0 h}$ & $\mathbf{1} \mathbf{h}$ & $\mathbf{3 h}$ & $\mathbf{5 h}$ \\
\hline medium & $5.4^{*}$ & 8.2 & 10.3 & 12.9 \\
TNF+CHX & & 4.4 & 47.7 & 51.4 \\
$1 \mu \mathrm{M} \mathrm{AA}$ & & 2.7 & 11.4 & 14.3 \\
$10 \mu \mathrm{M} \mathrm{AA}$ & & 11.5 & 13.7 & 25.6 \\
$20 \mu \mathrm{M} \mathrm{AA}$ & & 4.6 & 24.4 & 36.5 \\
\hline
\end{tabular}

*Percentage of cells having nuclear fragmentation, as determined by Hoechst 33342 staining. Data are from a representative experiment performed in duplicate.

$\mathrm{CPLA}_{2}$ plays an important role in basal phospholipid metabolism and signal transduction (Dennis, 1994). We found that BW A4C, BW B70C, MK-886 and $\mathrm{AACOCF}_{3}$ partially inhibited basal $\mathrm{CPLA}$ activity in U937 cells. Recent studies have implicated $\mathrm{CPLA}_{2}$ in lymphocyte maturation (Feltenmark et al, 1995) and apoptosis (Gilbert et al, 1996). It is plausible that basal rather than TNF-stimulated $\mathrm{CPLA}_{2}$ activity is an important homeostatic mechanism. The capacity of these compounds to inhibit apoptosis could be due to interference with basal cPLA ${ }_{2}$ activity.

Although we did not find an increase in $\mathrm{CPLA}_{2}$ activity or AA release, as consequence of TNF plus $\mathrm{CHX}$ stimulation, there was a clear induction of nuclear fragmentation following incubation of U937 cells with AA. Our results differ from previous reports describing an increase in $\mathrm{PLA}_{2}$ activity and AA release after TNF plus $\mathrm{CHX}$ treatment in various cell types, including U937 (Neale et al, 1988; McEwan, 1996; Voelkel-Johnson et al, 1996). Our inability to detect $A A$ release from intact cells could be explained by a rapid, transient or variable rise in $A A$, reincorporation of AA into cellular lipids by reacylation (Cissel et al, 1996), or clonal diversity (Withnall et al, 1995).

Other studies indicate that $\mathrm{CPLA}_{2}$ and 5-LO are translocated to the nuclear membrane after activation of peritoneal macrophages by ionophore A23187 (PetersGolden and McNish, 1993). 5-LO is primarily nuclear membrane bound in human B-lymphocytes (Jakobsson et al, 1995), and PGH synthase I and PGH synthase II are also localised at this site (Regier et al, 1993). Furthermore, it has been reported that $A A$ released after receptor stimulation originates from nuclear membrane phospholipids (Capriotti et al, 1988). AA metabolites are important messengers for signalling between cells. It is also possible that AA or its metabolites have a significant role within cells by transmitting signals to the nucleus. $\mathrm{CPLA}_{2}$ translocation to nuclear membranes during apoptosis could explain the lack of detectable AA in the present study.

The relative importance of nuclear and cytosolic events in the development of apoptosis remains controversial. Chromatin condensation and nuclear fragmentation can be observed in cell free systems, and membrane and cytosolic alterations occur in enucleated cells (Schultze-Osthoff et al, 1994; Newmeyer et al, 1994). Although further work is necessary to define interactions between apoptosis and AA metabolism, the ability of these inhibitors to interfere with $\mathrm{CPLA}_{2}$ activity and DNA fragmentation may be an important tool to make a distinction between cytoplasmic and nuclear events that lead to cell death. 


\section{Materials and Methods}

\section{Reagents}

Human TNF was a kind gift from Dr Grace Wong (Genentech Inc., San Francisco, CA). MK-886 was kindly given by $\mathrm{Dr}$ Anthony FordHutchinson (Merck Frosst Centre for Therapeutic Research; Quebec, Canada). BW A4C and BW B70C were kindly donated by Dr Lawrence G. Garland (Wellcome Research Laboratories; Kent, UK). AACOCF 5-HPETE and arachidonic acid were from Biomol (Plymouth Meeting, PA). CHX, poly-L-Lysine, trypan blue, propidium iodide, and phorbol 12-myristate 13-acetate were from Sigma Chemical (St. Louis, MO). Hoechst 33342 was from Molecular Probes Inc. (Eugene, OR). Apoptest was purchased from Nexins (Hoeven, Netherlands). Phenol, chloroform, DTT, HEPES and sucrose were purchased from Fluka (Buchs, Switzerland). RNAsin and Taq polymerase were from SDS (Falkenberg, Sweden). DTT, Moloney murine leukemia virus reverse transcriptase (M-MLV RT) and first strand buffer were from GIBCO BRL (Gaithersburg, MD). Random primers ( $\mathrm{pd}(\mathrm{N}) 6)$, ultrapure dNTP and agarose NA were obtained from Pharmacia AB (Uppsala, Sweden). HPLC solvents were purchased from Rathburn Chemicals (Walkerburn UK). Monoflow 2 scintillation liquid was obtained from National Diagnostics (Manville, NJ). 1-palmitoyl 2-[1- $\left.{ }^{14} \mathrm{C}\right]$ arachidonyl phosphatidylcholine (PC) was obtained from New England Nuclear (Dierech, Germany). FPLC System and protein purification columns were from Pharmacia Biotech (Uppsala, Sweden). DEVD-AMC was from Bachem (Bubendorf, Switzerland).

\section{Cell culture}

The U937 human monoblastoid cell line was cultured in RPMI 1640 medium supplemented with 10\% FCS, 2 mM glutamine, penicillin and streptomycin in a humidified atmosphere of $5 \% \mathrm{CO}_{2}$ in air at $37^{\circ} \mathrm{C}$ (Sundstrom and Nilsson, 1976). Cells were kept undifferentiated by culturing for short periods and thawing a fresh aliquot of cells every three months. Cells were incubated at $1 \times 10^{6} / \mathrm{ml}$ in six well plates, during $5 \mathrm{~h}$ in the presence or in the absence of TNF $(12 \mathrm{ng} / \mathrm{ml})$ plus CHX $(1 \mu \mathrm{g} / \mathrm{ml}) .5-\mathrm{LO}, \mathrm{FLAP}$ and $\mathrm{cPLA}_{2}$ inhibitors were added $5 \mathrm{~min}$ before TNF plus $\mathrm{CHX}$, at concentrations between $0.1 \mu \mathrm{M}$ and $10 \mu \mathrm{M}$ and were present in the correspondent cultures during the whole experiment. Cell viability was analyzed at various time points by trypan blue exclusion.

\section{Flow cytometry}

After incubation with or without TNF plus $\mathrm{CHX}$ and the various inhibitors, cells were fixed with $4 \%$ PFA, at various time points. Samples were analyzed by flow cytometry (FACS) using a Becton Dickinson FACScan flow cytometer equipped with a $15 \mathrm{~mW}, 488 \mathrm{~nm}$ air cooled argon laser. 10000 cells were acquired for each determination, with a rate lower than 400 events/sec.

\section{Phosphatidylserine (PS) exposure}

PS exposure during apoptosis was quantitated by measuring the binding of annexin V-FITC with the Apoptest binding kit (Dachary-Prigent et al, 1993). Cells were stained with annexin V-FITC and propidium iodide (PI, $100 \mu \mathrm{g} / \mathrm{ml}$ ) and analyzed by flow cytometry for the simultaneous determination of PS exposure and cell membrane integrity.

\section{Caspase 3-like activation}

Caspase 3-like enzyme activity was measured by the ability to cleave the peptide substrate Asp-Glu-Val-Asp (DEVD) linked to amino-4methylcoumarin (AMC) in a fluorometric assay modified from
Nicholson (Nicholson et al, 1995). Cell lysate and substrate were combined in a standard ICE reaction buffer (100 mM HEPES, $10 \%$ sucrose, $5 \mathrm{mM}$ DTT, $0.1 \%$ CHAPS; pH 7.25). Cleavage was monitored by AMC liberation using $355 \mathrm{~nm}$ excitation and $460 \mathrm{~nm}$ emission wave lengths. Fluorescence units were converted to pmoles of AMC using a standard curve with increasing doses of AMC against fluorescence (Thornberry et al, 1992).

\section{Nuclear fragmentation}

U937 cells were harvested, pelleted and resuspended in $4 \%$ paraformaldehyde (PFA) in PBS, in order to spread $0.3 \times 10^{6}$ cells on poly-L-lysine $(100 \mu \mathrm{g} / \mathrm{ml})$ treated glass microscope slides that were left to dry. Cells were rehydrated and stained with Hoechst 33342 $(10 \mu \mathrm{g} / \mathrm{ml})$ for $10 \mathrm{~min}$, rinsed with water, dried in the dark and covered with glycerol/PBS (50/50) and a coverslip. At least 200 cells were analyzed by examining the fluorescent nuclei with a fluorescence microscope.

\section{High MW and oligonucleosomal DNA fragments}

The presence of High MW DNA fragments was analyzed with field inversion gel electrophoresis (Brown et al, 1993). After incubation, $10^{6}$ cells were pelleted, resuspended in $50 \mu \mathrm{l}$ PBS and mixed with $50 \mu \mathrm{l}$ of $1 \%$ low-melting-point agarose. The agarose plugs were digested for $48 \mathrm{~h}$ with pronase $(1 \mathrm{mg} / \mathrm{ml})$ at $50^{\circ} \mathrm{C}$. High MW DNA fragments were electrophoresed and photographed with UV illumination. Analysis of oligonucleosomal DNA fragments was performed as described by Sorenson (Sorenson et al, 1990). After incubation $10^{6}$ cells were pelleted, resuspended in $10 \mu \mathrm{l}$ PBS, $5 \mu \mathrm{l}$ RNAse $(50 \mathrm{mg} / \mathrm{ml})$ and $5 \mu \mathrm{l}$ loading buffer $(0.25 \%$ bromophenol blue, $30 \%$ glycerol) and $10 \mu \mathrm{l}$ of sample were loaded in a $1.8 \%$ agarose gel, with a precast digestion gel containing $2 \%$ SDS and $1 \mathrm{mg} / \mathrm{ml}$ proteinase $\mathrm{K}$ in $0.8 \%$ agarose. The gel was electrophoresed overnight at $20 \mathrm{~V}$ followed by $3 \mathrm{~h}$ at $90 \mathrm{~V}$, and stained with ethidium bromide.

\section{RNA extraction, CDNA and PCR amplification}

Total RNA was isolated (Chomczynski and Saachi, 1987) and quantitated by spectrophotometry. $2 \mu \mathrm{g}$ RNA were reverse transcribed and tested for PCR amplification with specific primers (Feltenmark et al, 1995). $2 \mu \mathrm{l}$ of cDNA were mixed with $46 \mu \mathrm{l}$ of the amplification mixture containing Taq polymerase buffer, $0.2 \mathrm{mM}$ dNTP, $0.5 \mu \mathrm{M}$ each of $5^{\prime}$ and $3^{\prime}$ primers, $2 \mathrm{U}$ Taq polymerase, and $0.5 \mathrm{mM} \mathrm{MgCl}_{2}$ (for 5-LO and FLAP) or $1.0 \mathrm{mM} \mathrm{MgCl}_{2}$ (for $\beta$ actin, $\mathrm{CPLA}_{2}, \mathrm{LTA}_{4}$ hydrolase, PGH synthase 1 and PGH synthase 2). PCR amplification was run for 25 cycles ( $\beta$ actin, $\mathrm{LTA}_{4}$ hydrolase and FLAP) or 34 cycles ( $\mathrm{CPLA}_{2}, 5-\mathrm{LO}, \mathrm{PGH}$ synthase 1 and PGH synthase 2) with $60^{\circ} \mathrm{C}$ as annealing temperature (Feltenmark et al, 1995).
$\beta$ actin
5'-GAGGAGCACCCCGTGCTGCTGA-3' 5'-CTAGAAGCATTTGCGGTGG-3'
cPLA $_{2}$ 5'-TTGCAAACTGCCTCAGCATCAG-3' 5'-CTCTAGTCCTCCGTTCAAGGAAC-3'
5-LO 5'-ACCATTGAGCAGATCGTGGACACGC-3' 5'-GCAGTCCTGCTCTGTGTAGAATGGG-3'
FLAP 5'-GGCCATCGTCACCCTCATCAGCG-3' 5'-GCCAGCAACGGACATGAGGAACAGG-3'
LTA $_{4}$ hydrolase 5'-GAACAACTGCTTGGAGGACCAGAG-3' 5'-TGCAGTCACGGGATGCATGCTTGC-3'
$\mathrm{PGH}_{\text {synthase } 1 \quad 5 ' \text {-CCTACACCTCCTTCCAGGAGCTC-3' }}$ 5'-AGACCAGCTTCTTCAGTGTGGCCG-3'
784 bp $554 \mathrm{bp}$ $488 \mathrm{bp}$ $352 \mathrm{bp}$ $624 \mathrm{bp}$ $285 \mathrm{bp}$ $\mathrm{PGH}_{\text {synthase } 2}$ 5'-TTCAAATGAGATTGTGGGAAAATTGCT-3' $305 \mathrm{bp}$ 5'-AGATCATCTCTGCCTGAGTATCTT-3' 


\section{Purification of $\mathrm{CPLA}_{2}$}

Liquid chromatography was performed on a Pharmacia FPLC System. All buffers were made fresh, passed through a $0.22 \mu \mathrm{m}$ filter and degassed before use. U937 cells were sonicated twice for $5 \mathrm{~s}$. The cell homogenate was centrifuged at $10^{5} \times g$ for 60 min to obtain cytosolic and membrane fractions. The $10^{5} \times g$ supernatant, from 25 to $30 \mathrm{mg}$ of protein, obtained from U937 cell homogenate, was applied to a Resource-Q $6 \mathrm{ml}$ column pre-equilibrated with buffer A [20 mM Tris$\mathrm{HCl}(\mathrm{pH} 7.5), 1 \mathrm{mM}$ EGTA, $1 \mathrm{mM}$ EDTA and $0.5 \mathrm{mM}$ DTT]. After washing, a gradient was developed from $0.2 \mathrm{M}$ to $0.6 \mathrm{M} \mathrm{NaCl}$ in buffer $A$ at a flow rate of $3 \mathrm{ml} / \mathrm{min}$. Fractions of $1.5 \mathrm{ml}$ were collected and $15 \mu \mathrm{l}$ aliquots were assayed for $\mathrm{CPLA} 2$ activity. $\left(\mathrm{NH}_{4}\right)_{2} \mathrm{SO}_{4}(1 \mathrm{M}$ final concentration) was added to pooled, active fractions from the Resource-Q column and applied to a Phenyl-Superose HR 5/5 column pre-equilibrated with $1 \mathrm{M}\left(\mathrm{NH}_{4}\right)_{2} \mathrm{SO}_{4}$ in buffer $A$. Proteins were eluted in a stepwise gradient from $1 \mathrm{M}$ to $0 \mathrm{M}\left(\mathrm{NH}_{4}\right)_{2} \mathrm{SO}_{4}$ at a flow rate of $0.3 \mathrm{ml} / \mathrm{min}$. Fractions of $0.5 \mathrm{ml}$ were collected and $15 \mu \mathrm{l}$ aliquots of these were assayed for $\mathrm{CPLA}$ activity. Thus purified, pooled active fractions were further analyzed for $\mathrm{CPLA}_{2}$ content by Western blot. This partially purified $\mathrm{CPLA}{ }_{2}$ was used for activity studies with the different inhibitors. Protein concentrations were measured with a kit against BSA as standard protein (Bio-Rad, USA), essentially according to Lowry et al. (1951).

\section{PLA 2 assay}

$\mathrm{PLA}_{2}$ activity was assayed with 1-palmitoyl 2-[1-14C]arachidonyl phosphatidylcholine (PC) as standard substrate. The phospholipid was dried under nitrogen and resuspended in assay buffer [80 $\mathrm{mM}$ glycine, (pH 9.0), $5 \mathrm{mM} \mathrm{CaCl}$, $5 \mathrm{mM}$ DTT, $1 \mathrm{mg} / \mathrm{ml}$ albumin and $10 \%$ glycerol] to yield a final concentration of $2 \mu \mathrm{M} \mathrm{PC}$. This preparation $(57 \mathrm{nCi})$ was subsequently sonicated in a water bath for $10 \mathrm{~min}$ at $4^{\circ} \mathrm{C}$. The reaction was initiated by adding either homogenate or purified $\mathrm{PLA}_{2}$ and the reaction proceeded for $30 \mathrm{~min}$ at $37^{\circ} \mathrm{C}$. The reaction was terminated with two volumes of methanol with $0.5 \%$ acetic acid and $40 \mu \mathrm{M}$ stearic acid. Precipitated proteins and cell debris were removed by centrifugation $(800 \times g, 10 \mathrm{~min})$. The resulting supernatants were applied to a octadecyl reversed-phase disposable column (Chromabond C18, $100 \mathrm{mg}$; Macherey-Nagel, Duren, Germany). After washing, bound materials were eluted with $500 \mu \mathrm{l}$ methanol. The samples were analyzed in a reverse-phase (RP) HPLC system equipped with a Radial-Pak cartridge $(5 \times 100 \mathrm{~mm})$ packed with $4 \mu \mathrm{m}$ Novapak $\mathrm{C} 18$ material, guarded by Novapak $\mathrm{C} 18$ column (Waters associated; Milford, MA, USA). The mobile phase was methanol:water:trifluoroacetic acid $(85: 15: 0.007)$ and the flow rate was $1.2 \mathrm{ml} / \mathrm{min}$. Analysis was performed by comparing retention times with authentic standards. Radioactivity was detected with a $\beta$-RAM HPLC flow-through monitor system (Inus System Inc., USA). Quantitative determination was performed by peak area integration.

\section{AA release from intact U937 cells}

Cells were adjusted to $2 \times 10^{6} / \mathrm{ml}$ in RPMI 1640 and labelled with $0.2 \mu \mathrm{Ci} / \mathrm{ml}$ of $\left(5,6,8,9,11,12,14,15-{ }^{3} \mathrm{H}\right.$ )-AA (New England Nuclear, Germany) for $90 \mathrm{~min}$ at $37^{\circ} \mathrm{C}$. The cells were washed twice to remove unincorporated ${ }^{3} \mathrm{H}-\mathrm{AA}$, and resuspended at $1 \times 10^{7} / \mathrm{ml}$. Typically, 80 to $90 \%$ of the added ${ }^{3} \mathrm{H}$-AA was incorporated into the cells. Cell culture was stopped at various times either with two volumes of $0.5 \%$ acetic acid and $40 \mu \mathrm{M}$ stearic acid in methanol, or with $5 \mathrm{ml}$ acidified $(\mathrm{HCl})$ Folch solution (choloroform:methanol, 2:1). Released fatty acids were extracted and analyzed by RP-HPLC. Alternatively, AA release was measured by GC-MS. Briefly, the reactions were stopped with $5 \mathrm{ml}$ Folch solution. The samples were acidified by $\mathrm{HCl}$ and butylhydroxytoluene was added as anti-oxidant. Deuterium-AA (d8AA) $(5.9 \mathrm{nM})$ was added as an internal standard and the samples were vigorously mixed. The chloroform phase was collected and dried under nitrogen. The fatty acids were resuspended in SP-HPLC mobile phase of hexane: isopropanol:acetic acid (99.5:0.5:0.02 vol) and separated by SP-HPLC on a Nucleosil 55 column. AA was collected, dried, resuspended in ether and analyzed by GC-MS.

\section{Statistical analysis}

One way ANOVA and Mann Whitney-U were used as parametric and non-parametric tests to analyze the data.

\section{Acknowledgements}

This work has been supported by the Swedish Medical Research Council (O3X-07135), the Swedish Council for Work Life Research, the Lars Hiertas Foundation and the Karolinska Institute. We are indebted to $\mathrm{Dr}$ Grace Wong for the human TNF, Dr Anthony Ford-Hutchinson for the MK886, Dr Lawrence G Garland for the BW A4C and BW B70C compounds, and Dr D Nicholson for DEVD-CHO.

\section{References}

Agarwal ML, Larkin HE, Zaidi SIA, Mukhtar H and Oleinick NL (1993) Phospholipase activation triggers apoptosis in photosensitized mouse lymphoma cells. Cancer Res. 53: $5897-5902$

Aggarwal BB and Natarajan K (1996) Tumor necrosis factors: developments during the last decade. Eur. Cytokine Netw. 7: 93-124

Anderson KM, Levin J, Jajeh A, Seed T and Harris JE (1993) Induction of apoptosis in blood cells from a patient with acute myelogenous leukemia by SC41661A, a selective inhibitor of 5-lipoxygenase. Prostaglandins Leukotrienes Essential Fatty Acids 48: 323-326

Anderson KM, Seed T, Plate JMD, Jajeh A, Meng J and Harris JE (1995) Selective inhibitors of 5-lipoxygenase reduce CML blast cell proliferation and induce limited differentiation and apoptosis. Leukemia Res. 19: 789-801

Beyaert R and Fiers W (1994) Molecular mechanisms of tumor necrosis factorinduced cytotoxicity. What do we understand and what we do not. FEBS letters 340: $9-16$

Brown DG, Sun XM and Cohen GM (1993) Dexamethasone-induced apoptosis involves cleavage of DNA to large fragments prior to internucleosomal fragmentation. J. Biol. Chem. 268: 3037-3039

Capriotti AM, Furth EE, Arrasmith ME and Laposata M (1988) Arachidonatereleased upon agonist stimulation preferentially originates from arachidonate most recently incorporated into nuclear membrane phospholipids. J. Biol. Chem. 263 $10029-10034$

Chang DJ, Ringold GM and Heller RA (1992) Cell killing and induction of manganous superoxide dismutase by tumor necrosis factor- $\alpha$ is mediated by lipoxygenase metabolites of arachidonic acid. Biochem. Biophys. Res. Comm. 188: 538-546

Chomczynski P and Saachi N (1987) Single-step method of RNA isolation by acid guanidinium thiocyanate-phenol-choloroform extraction. Analytical Biochemistry 162: $156-159$

Cissel DS, Murty M, Whipkey DL, Blaha JD, Graeber GM and Keeting PE (1996) Estrogen pretreatment increases arachidonic acid release by bradykinin stimulated normal human osteoblast-like cells. J. Cell Biochem. 60: 260-270

Claesson HE, Odlander B and Jakobsson PJ (1992) Leukotriene B4 in the immune system. Int. J. Immunopharmac. 14: 441-449

Claesson HE, Jakobsson PJ, Steinhilber D, Odlander B and Samuelsson B (1993) Expression of 5-lipoxygenase and biosynthesis of leukotriene B4 in human monomorphonuclear leukocytes. J. Lipid Med. 6: 15-22

Dachary-Prigent J, Freyssinet JM, Pasquet JM, Carron JC and Nurden AT (1993) Annexin $\mathrm{V}$ as a probe of aminophospholipid exposure and platelet membrane vesiculation: a flow cytometry study showing a role for free sulfhydryl groups. Blood 81: 2554-2565

Dennis EA (1994) Diversity of group types, regulation, and function of phospholipase $A_{2}$. J. Biol. Chem. 269: 13057-13060 
Feltenmark S, Runarsson G, Larsson P, Jakobsson PJ, Björkholm M and Claesson HE (1995) Diverse expression of cytosolic phospholipase $A_{2}$, 5-lipoxygenase and prostaglandin $\mathrm{H}$ synthase 2 in acute pre-B-lymphocytic leukaemia cells. $\mathrm{Br}$. J. Haematol. 90: 585-594

Ford-Hutchinson AW, Gresser M and Young RN (1994) 5-lipoxygenase. Annu. Rev. Biochem. 63: 383-417

Fraser A and Evan G (1996) A license to kill. Cell 85: 781 - 784

Garland LG and Hodgson ST (1994) Inhibition of leukotriene production by inhibitors of lipoxygenation. Adv. Prostaglandin Thromboxane Leukotriene Res. 22: 33 48

Gilbert JJ, Stewart A, Courtney C-A, Fleming M-C, Reid P, Jackson CG, Wise A, Wakelam MJO and Harnett MM (1996) Antigen receptors on immature, but not mature, $B$ and T cells are coupled to cytosolic phospholipase $A_{2}$ activation. J. Immunol. 156: 2054-2061

Gillard J, Ford-Hutchinson AW, Chan C, Charleson S, Denis D, Foster A, Fortin $\mathrm{R}$, Leger S, McFarlane CS, Morton H, Piechuta H, Riendeau D, Rouzer CA Rokach J, Young R, Macintyre DE, Peterson L, Bach T, Eiermann G, Hopple S, Humes J, Hupe L, Luell S, Metzger J, Meurer R, Miller DK, Opas E and Pacholok S (1989) L-663,536 (MK-886) (3-(1-(4-chlorobenzyl)-3-tbutyl-thio-5-isoprolyndol-2-yl)-2,2-dimethylpropanoic acid), a novel, orally active leukotriene byosinthesis inhibitor. Can. J. Physiol. Pharmacol. 67: $456-464$

Hamberg M, Svensson J and Samuelsson B (1975) Thromboxanes: a new group of biologically active compounds derived from prostaglandin endoperoxides. P.N.A.S. (USA) 72: 2994-2998

Hollenback PW, Zilli DL and Laster SM (1992) Inhibitors of transcription and translation act synergistically with tumor necrosis factor to cause the activation of phospholipase A. J. Biol. Chem. 267: 39-42

Jakobsson PJ, Shaskin P, Larsson P, Feltenmark S, Odlander B, Aguilar-Santelises M, Jondal M, Biberfeld P and Claesson HE (1995) Studies on the regulation and localization of 5-lipoxygenase in human B-lymphocytes. Eur. J. Biochem. 232: $37-46$

Lowry O, Rosebrough NJ, Farr AL and Randall RJ (1951) Protein measurement with the Folin phenol reagent. J. Biol. Chem. 193: 265-275

MacEwan DJ (1996) Elevated cPLA 2 levels as a mechanism by which the p70 TNF and p75 NGF receptors enhance apoptosis. FEBS let. 379: 77-81

Neale ML, Fiera RA and Matthews N (1988) Involvement of phospholipase $A_{2}$ activation in tumor cell killing by tumor necrosis factor. Immunology 64 : $81-85$

Newmeyer DD, Farschon DM and Reed JC (1994) Cell-free apoptosis in Xenopus egg extracts: inhibition by $\mathrm{Bcl}-2$ and requirement for an organelle fraction enriched in mitochondria. Cell 79: 353-364

Nicholson DW, Ali A, Thornberry NA, Vaillancourt JP, Ding CK, Gallant M, Gareau Y, Griffin PR, Labelle M, Lazebnik YA, Munday NA, Rayu SM, Smulson ME, Yamin TT, Yu VL and Miller DK (1995) Identification and inhibition of the ICE/CED-3 protease necessary for mammalian apoptosis. Nature 376: $37-43$

O'Donnell VB,Spycher S and Azzi A (1995) Involvement of oxidants and oxidantgenerating enzyme(s) in tumor necrosis factor ${ }_{\alpha}$-mediated apoptosis: role for lipoxygenase pathway but not mitochondrial respiratory chain. Biochem. J. 310: $133-141$

Peters-Golden M and McNish RW (1993) Redistribution of 5-lipoxygenase and cytosolic phospholipase $A_{2}$ to the nuclear fraction upon macrophage activation. Biochem. Biophys. Res. Comm. 196: 147-153
Regier MK, DeWittDL, Schindler MS and Smith WL (1993) Subcellular localisation of prostaglandin endoperoxide synthetase-2 in murine 3T3 cells. Arch. Biochem. Biophys. 301: 439-444

Riendeau D, Guay J, Weech PK, Laliberte F, Yergey J, Li C, Desmarais S, Perrier H, Liu S, Nicoll-Griffith D and Street IP (1994) Arachidonyl trifluoromethyl ketone, a potent inhibitor of $85-\mathrm{kDa}$ phospholipase $\mathrm{A}_{2}$, blocks production of arachidonate and 12-hydroxyeicosatetraenoic acid by calcium ionophore-challenged platelets. J. Biol. Chem. 269: 15619-15624

Schulze-Osthoff K, Walczak H, Dröge W and Krammer PH (1994) Cell nucleus and DNA fragmentation are not required for apoptosis. J. Cell. Biol. 127: 15-20

Schütze S, Machleidt T and Krönke M (1992) Mechanism of tumor necrosis factor action. Semin. Oncol. 19(S4): 16-24

Sorenson CM, Barry MA and Eastman A (1990) Analysis of events associated with cell cycle arrest at G2 phase and cell death induced by cisplatin. J. Natl. Cancer Inst. 82: $749-755$

StellerH(1995) Mechanisms and genes of cellular suicide. Science 267: 1445-1449

Sundstrom C and Nilsson K (1976) Establishment and characterisation of a human histiocytic lymphoma cell line (U937). Int. J. Cancer 17: 565-577

Tanaka K, Itazaki $\mathrm{H}$ and Yoshida $\mathrm{T}$ (1992) Cinatrins a novel family of PLA 2 inhibitors. J. of Antibiotics 45: 50-55

Tang DG, Chan YQ and Honn KV (1996) Arachidonate lipoxygenases as essential regulators of cell survival and apoptosis. PNAS (USA) 93: 5241-5246

Tewari M, Quan LT, O'Rourke K, Desnoyers S, Zeng Z, Beidler DR, Poirier GG, Salvesen GS and Dixit VM (1995) Yama/CPP32 $\beta$, a mammalian homologue of CED-3, is a Crm-A-inhibitable protease that cleaves the death substrate poly(ADP-ribose) polymerase. Cell 81: 801-809

Thornberry NA, Bull HG, Calaycay JR, Chapman KT, Howard AD, Kostura MJ, Miller DK, Molineaux SM, Weidner JR, Aunins J, Elliston KO, Ayala JM, Casano FJ, Chin J, Ding GJF, Egger LA, Gaffney EP, Limjuco G, Palyha OC, Raju SM, Rolando AM, Salley JP, Yamin TT, Lee TD, Shively JE, MacCross M, Mumford RA, Schmidt JA and Tocci MJ (1992) A novel heterodimeric cysteine protease is required for interleukin-1 $\beta$ processing in monocytes. Nature 356: $768-774$

Tsujii M and Dubois RN (1995) Alterations in cellular adhesion and apoptosis in epithelial cells overexpressing prostaglandin endoperoxide synthase 2. Cell 83: 493-501

Vanags DM, Pörn-Ares MI, Copola S, Burgess DH and Orrenius S. (1996) Protease involvement in fodrin cleavage and phospatidylserine exposure in apoptosis. J. Biol. Chem. 271: 31075-31085

Voelkel-Johnson C, Thorne TE and Laster SM (1996) Susceptibility to TNF in the presence of inhibitors of transcription or translation is dependent on the activity of cytosolic phospholipase $A_{2}$ in human melanoma tumor cells. J. Immunol. 156: 201-207

Withnall MT, Pennington A and Wiseman D (1995) Characterisation of cytosolic phospholipase $\mathrm{A}_{2}$ as mediator of the enhanced arachidonic acid release from dimethyl sulphoxide differentiated U937 cells. Biochem. Pharmacol. 50: 18931902

Zhivotovsky B, Burgess DH and Orrenius S (1996) Proteases in apoptosis. Experientia 52: 968-978 